\title{
MENINGKATKAN KEMAMPUAN PESERTA DIDIK DALAM MENGGALI INFORMASI PENTING PADA TEKS NARASI SEJARAH BERBANTUAN VIDEO PEMBELAJARAN DI KELAS VI SDN 1 DOPANG
}

\author{
Sri Muryanti ${ }^{1, *)} \&$ Baiq Syahruniwati ${ }^{2)}$ \\ ${ }^{1), 2)}$ SD Negeri 1 Dopang, Lombok Barat, Indonesia \\ E-mail: asrimuryanti66@gmail.com
}

\begin{tabular}{l}
\hline ARTICLE INFO \\
\hline Article history \\
Received: August 10, 2020 \\
Revised: August 14, 2020 \\
Accepted: August 16, 2020 \\
Kata Kunci: \\
bahasa Indonesia, teks, narasi, \\
sejarah, video pembelajaran
\end{tabular}

\begin{abstract}
ABSTRAK
Kemampuan menggali informasi penting dalam teks narasi sejarah merupakan salah satu kemampuan penting yang harus dimiliki oleh peserta didik tingkat sekolah dasar pada materi Bahasa Indonesia. Berdasarkan analisis hasil pretest peserta didik kelas VI tentang kemampuan peserta didik dalam menggali informasi penting pada teks narasi sejarah di SDN 1 Dopang diperoleh bahwa peserta didik masih kesulitan dalam mengelompokkan informasi menggunakan aspek: apa, siapa, kapan, di mana, mengapa, serta bagaimana. Dengan pembelajaran dimasa pandemi covid-19 yang mengharuskan pembelajaran secara daring, pendidik berupaya menggunakan video pembelajaran sebagai media dalam membelajarkan kemampuan menggali informasi penting pada teks narasi sejarah yang termasuk dalam kompetensi dasar bahasa Indonesia. Oleh karena itu penelitian ini bertujuan untuk meningkatkan kemampuan peserta didik dalam menggali informasi penting pada teks narasi sejarah berbantuan video pembelajaran di kelas VI (enam) SDN 1 Dopang. Penelitian ini merupakan penelitian tindakan kelas (PTK) yang dilakukan sebanyak dua siklus. Tiap siklus terdiri atas tahap perencanaan, pelaksanaan dan observasi, serta refleksi. Data dalam penelitian ini dikumpulkan dengan teknik tes. Hasil penelitian menunjukkan bahwa pada siklus I diketahui rata-rata nilai kemampuan peserta didik dalam menggali informasi penting pada teks narasi sejarah adalah 59,38 dan pada siklus II terjadi peningkatan yang signifikan menjadi 82,50 sehingga dapat disimpulkan bahwa pembelajaran berbantuan video pembelajaran dapat meningkatkan kemampuan peserta didik kelas VI SDN 1 Dopang dalam menggali informasi penting pada teks narasi sejarah.
\end{abstract}

\section{A. PENDAHULUAN}

Manusia sebagai makhluk sosial tidak dapat lepas dan saling membutuhkan satu sama lain. Sebagai makhluk berkelompok dan bersosial dalam kehidupan sehari-hari tentunya manusia harus selalu berinteraksi dan berkomunikasi satu sama lain (Inah, 2013). Untuk menjalin hubungan interaksi dan komunikasi yang baik, manusia memerlukan alat komunikasi yaitu bahasa (Rahayu, 2013). Dengan berbahasa manusia mampu mengutarakan maksud dan pikiran, perasaan, dan keinginannya kepada orang lain. Oleh karena itu, tidak mengherankan jika kemampuan literasi bahasa yang termasuk dalam literasi baca tulis merupakan salah satu keterampilan literasi yang wajib dikuasai oleh peserta didik khususnya di tingkat sekolah dasar. 
Dalam kurikulum 2013 pada tingkat sekolah dasar, mata pelajaran bahasa Indonesia memiliki kedudukan yang sangat strategis. Mata pelajaran bahasa Indonesia berperan sebagai saluran yang menghantarkan kandungan materi mata pelajaran lain atau dengan kata lain, kandungan materi mata pelajaran lain dijadikan sebagai konteks dalam penggunaan jenis teks yang sesuai dalam mata pelajaran bahasa Indonesia (Akhyar, 2019).

Merebaknya pandemi corona virus desease (Covid-19) pada kuartal pertama tahun 2020 tentunya berdampak pada kegiatan belajar mengajar di berbagai tingkat satuan pendidikan tidak terkecuali di tingkat sekolah dasar. Kegiatan pembelajaran yang semula dilakukan secara tatap muka (luring) kini berubah menjadi secara daring (online). Dengan adanya penyesuaian kegiatan belajar mengajar karena adanya pandemi ini tentunya tidak harus membuat berbagai kompetensi inti dan kompetensi dasar yang wajib dikuasai peserta didik tingkat sekolah dasar menjadi terabaikan, namun metode pendidik dalam membelajarkan berbagai kompetensi inti dan kompetensi dasar yang wajib disesuaikan agar berbagai kompetensi tersebut tetap bisa dipelajari dan dikuasai oleh peserta didik.

Salah satu kompetensi inti yang wajib dikuasai oleh peserta didik tingkat sekolah dasar khususnya kelas VI (enam) adalah kemampuan menggali informasi penting dari buku sejarah dengan menggunakan aspek: apa, di mana, kapan, siapa, mengapa, dan bagaimana serta peserta didik memperhatikan penggunaan kosakata baku dan kalimat efektif. Kompetensi ini dapat dianggap sebagai kompetensi yang penting karena dari kompetensi inilah peserta didik dapat mempelajari berbagai informasi dapat memilah-milah informasi apa saja yang diperlukan dan informasi apa saja yang sekiranya kurang begitu penting.

Pembelajaran di SDN 1 Dopang Kecamatan Gunung Sari Kabupaten Lombok Barat khususnya pada bahasa Indonesia telah secara penuh menggunakan kurikulum 2013 dengan setiap topik pembelajaran disajikan secara bertema (tematik). Sebelum pandemi pembelajaran di SDN 1 Dopang seluruhnya dilakukan dengan tatap muka (luring) namun di saat pandemi pendidik di SDN 1 Dopang menyesuaikan proses belajar mengajar menjadi daring tak terkecuali di kelas VI (enam). Berdasarkan hasil pretest yang dilakukan pada peserta didik kelas VI pada materi menggali informasi penting pada teks narasi sejarah diperoleh nilai ratarata sebesar 48,44 yang termasuk dalam kategori rendah, hal rendahnya hasil pretest ini sebagian besar disebabkan oleh peserta didik masih merasa malas membaca teks narasi sejarah yang diberikan secara daring. Selain itu karena sebagian besar tidak adanya kontrol dari orang tua menyebabkan peserta didik menjadi tidak terfokus dalam belajar secara daring.

Berangkat dari faktor di atas, perlu dicarikan alternatif pemecahan masalah agar peserta didik tetap dapat menguasai kemampuan menggali informasi penting pada teks narasi sejarah 
walaupun dengan pembelajaran daring yang dilakukan dalam upaya mencegah penyebaran Covid-19.

\section{B. METODE PENELITIAN}

Penelitian ini merupakan penelitian tindakan kelas (classroom action research). Dalam kegiatan penelitian ini, yang melakukan tindakan adalah guru kelas dan otomatis guru terlibat secara langsung dalam proses penelitian dari awal. Penelitian ini di lakukan di kelas VI (enam) SDN 1 Dopang dengan subyek peserta didik sebanyak 32 orang. Teknik pengumpulan data yang digunakan dalam penelitian ini adalah teknik tes dengan 10 butir soal kemampuan menggali informasi penting pada teks narasi sejarah.

Proses penelitian dilaksanakan secara bersiklus dengan memperhatikan beberapa tahap penelitian tindakan di antaranya adalah plan, implementation, monitoring, serta implementation sebagaimana tahapan yang diperkenalkan oleh Kemmis and McTaggart (1988). Pada tahapan penelitian tindakan, bagian implementation sudah termasuk dalam bagian Action/Observation dan untuk bagian monitoring and reflection sudah termasuk dalam bagian Reflection.

Setiap akhir siklus, peneliti melakukan refleksi untuk perbaikan pada siklus selanjutnya. Dalam kegiatan refleksi, peneliti berusaha memahami dan mengevaluasi proses, masalah, persoalan, dan kendala nyata dalam tindakan yang telah dilakukan. Selanjutnya, untuk menghindari kendala yang sama, peneliti melakukan langkah-langkah antisipasi berdasarkan hasil analisis reflektif yang telah di lakukan.

Data dalam penelitian ini dianalisis dengan analisis deskriptif dengan jenis data yang diperoleh adalah data kuantitatif yang ditampilkan dan dibahas dalam bentuk tabel, gambar, serta ukuran-ukuran statistik deskriptif seperti rata-rata, nilai minimum maksimum, deviasi standar, serta untuk mengetahui seberapa tinggi peningkatan hasil belajar kognitif peserta didik pada tema perkalian dan pembagian pecahan digunakan uji gain ternormalisasi (N-Gain). Tinggi rendahnya gain score ternormalisasi dikategorikan dalam tiga kategori (tinggi, sedang, rendah) yang disajikan pada Tabel 1 (Cheng et al., 2004; Erfan et al., 2020).

Tabel 1. Kriteria Skor/Nilai Gain Ternormalisasi (Hake, 1998)

\begin{tabular}{cc}
\hline Kriteria Peningkatan Nilai Gain & Nilai Gain Ternormalisasi \\
\hline Gain tinggi & $\mathrm{g} \geq 0,7$ \\
Gain sedang & $0,3 \leq \mathrm{g}<0,7$ \\
Gain rendah & $\mathrm{g}<0,3$ \\
\hline
\end{tabular}

\section{HASIL DAN PEMBAHASAN}

1. Hasil Penelitian 
a. Hasil tahap perencanaan/plan siklus I

Pada tahapan perencanaan tindakan di siklus I, pendidik membuat rencana dan menyusun rancangan tindakan yang akan dilaksanakan sesuai dengan temuan masalah, gagasan awal serta situasi dan kondisi pelaksanaan belajar mengajar di SDN 1 Dopang. Pada tahap ini pendidik mengembangkan sendiri rencana pelaksanaan pembelajaran (RPP) dan lembar kerja peserta didik serta merancang soal pretest untuk mengetahui seberapa jauh pemahaman awal peserta didik dalam menggali informasi penting pada teks narasi sejarah.

Pembuatan lembar kerja peserta didik (LKPD) disusun berdasarkan Kompetensi Inti dan Kompetensi Dasar yang ingin dicapai satuan pendidikan sesuai dengan gugus sekolah dasar serta menyesuaikan dengan materi yang diajarkan yaitu menggali informasi penting dari buku sejarah menggunakan aspek apa, di mana, kapan, siapa, mengapa, dan bagaimana. Selain itu RPP yang dibuat juga dilengkapi dengan integrasi video pembelajaran dalam bentuk narasi yang dapat diakses melalui YouTube dan menyesuaikan situasi dan kondisi proses belajar mengajar yang dilakukan secara daring.

b. Hasil tahap action/observation siklus I

Kegiatan pembelajaran pada tahap action/observation siklus I dilangsungkan selama 2 kali pertemuan dengan pertemuan pertama kegiatan pembelajaran membahas tentang aspek apa, siapa, dan kapan yang ada pada teks narasi sejarah yang sudah disajikan pada video pembelajaran. Pertemuan kedua, kegiatan pembelajaran membahas tentang aspek di mana, mengapa, serta bagaimana yang ada pada teks narasi sejarah. Pada pertemuan kedua memerlukan waktu yang lebih lama karena aspek mengapa dan bagaimana tentunya menuntut peserta didik untuk mampu menjelaskan dan menceritakan bagaimana suatu peristiwa sejarah terjadi setelah peserta didik menonton video pembelajaran yang telah dibagikan pada masingmasing peserta didik.

Kegiatan pembelajaran pada siklus I baik pada pertemuan pertama maupun pada pertemuan kedua diawali dengan kegiatan apersepsi dan pemberian motivasi bagi peserta didik melalui pembelajaran daring. Pendidik menjelaskan mengenai kegiatan pembelajaran yang akan dilaksanakan, mengenai apa saja yang akan dipelajari serta capaian hasil belajar apa saja yang diharapkan dapat dicapai oleh peserta didik. Pada tahap ini guru juga menjelaskan mengenai teknis pelaksanaan pembelajaran berbantuan video pembelajaran. Setiap peserta didik diwajibkan untuk menonton suatu video narasi sejarah selanjutnya peserta didik menceritakan mengenai aspek apa, siapa, kapan, di mana, mengapa dan bagaimana suatu peristiwa sejarah itu terjadi dan berlangsung. 
Setelah semua kegiatan pembelajaran pada kompetensi menggali informasi penting dari buku sejarah menggunakan aspek: apa, di mana, kapan, siapa, mengapa, dan bagaimana, di akhir kegiatan dilakukan post-test untuk mengetahui apakah peserta didik telah menguasai kompetensi dasar yang ada pada tujuan pembelajaran yaitu peserta didik mampu memaparkan informasi penting dari buku sejarah secara lisan, tulis, dan visual dengan menggunakan aspek: apa, di mana, kapan, siapa, mengapa, dan bagaimana serta peserta didik mampu menggunakan kosa kata baku dan kalimat efektif. Selain itu Post-test dilakukan juga sebagai cara untuk mengetahui adanya umpan balik yang diperlukan sekiranya di dalam proses pembelajaran pada siklus I serta sebagai bahan refleksi untuk siklus berikutnya.

c. Hasil tahap reflection siklus I

Setelah kegiatan pada tahap action/observation siklus I dilaksanakan, terdapat beberapa catatan penting berkaitan jalannya proses pembelajaran berbantuan video pembelajaran untuk meningkatkan kemampuan peserta didik dalam menggali informasi penting dari teks narasi sejarah.

Secara umum dari proses pembelajaran yang dijalankan pada siklus I sebagian besar peserta didik masih dalam proses penyesuaian dengan pembelajaran daring berbantuan video pembelajaran. Selama proses pembelajaran, peranan pendidik masih diperlukan baik dalam proses pengelolaan waktu, pemberian materi serta pendidik masih perlu memancing peserta didik dengan pertanyaan-pertanyaan yang berkaitan dengan narasi yang ada di video pembelajaran. Selain itu, ketika peserta didik menonton video pembelajaran masih banyak yang memerlukan waktu untuk fokus.

Akhir kegiatan tahap action/observation siklus I dilakukan tahap post-test untuk melihat sejauh mana peningkatan capaian hasil belajar peserta didik dalam memaparkan informasi penting yang ada dalam teks narasi sejarah. Hasil statistik deskriptif yang menjadi acuan perencanaan kegiatan pada siklus selanjutnya ditunjukkan pada Tabel 2.

Tabel 2. Statistik deskriptif capaian hasil belajar siklus I

\begin{tabular}{cccc}
\hline Statistik Deskriptif & Pre-test & Post-test $\mathbf{1}$ & Gain Post-test I \\
\hline Nilai Maksimum & 60,00 & 80,00 & \\
Nilai Minimum & 40,00 & 50,00 & \\
Rerata (mean) & 48,44 & 59,38 & 0,21 \\
Median & 50,00 & 60,00 & (rendah) \\
Modus & 50,00 & 60,00 & \\
Std.deviasi & 7,23 & 8,78 & \\
\hline
\end{tabular}

Berdasarkan Tabel 2, diketahui bahwa peningkatan nilai rata-rata kemampuan peserta didik dalam menggali informasi penting dari teks narasi sejarah masih tergolong rendah. Hal 
ini dapat dilihat dari nilai Gain pada post-test I yang hanya 0,21 dengan kategori gain rendah. Dari nilai rata-rata dapat diketahui bahwa baik nilai pre-test maupun nilai post-test sama-sama berada di bawah nilai KKM (80).

d. Hasil tahap action/observation siklus II

Hasil refleksi pada siklus I menjadi umpan balik utama dalam pelaksanaan proses pembelajaran yang dilakukan pada siklus II. Proses pembelajaran pada siklus II lebih kurang sama dengan kegiatan pembelajaran pada siklus I namun terdapat beberapa hal yang ditambahkan dan beberapa hal yang perlu diberi perhatian khusus.

Hal yang ditambahkan dan diperbaiki pada kegiatan pembelajaran di siklus II adalah pada video pembelajaran sekaligus diberi subtitle, jadi selain peserta didik dapat melihat tampilan video dan mendengar suara narasi yang ada pada video, peserta didik juga dapat membaca teks yang ada pada video sehingga peserta didik dapat lebih fokus dalam mengamati jalannya video pembelajaran.

\section{e. Hasil tahap reflection siklus II}

Pada kegiatan tahap action/observation siklus II, sebagian besar peserta didik telah terbiasa dengan pembelajaran daring berbantuan video. Pada kegiatan inti siklus II ini pun pendidik lebih mudah dalam memberikan instruksi berkaitan dengan proses jalannya pembelajaran daring.

Akhir kegiatan tahap action/observation siklus II juga dilakukan tahap post-test untuk melihat sejauh mana peningkatan capaian peserta didik pada siklus II. Hasil statistik deskriptif yang menjadi acuan perencanaan kegiatan pada siklus selanjutnya ditunjukkan pada Tabel 3.

Tabel 3. Statistik deskriptif capaian hasil belajar siklus II

\begin{tabular}{cccc}
\hline Statistik Deskriptif & $\begin{array}{c}\text { Post-test I } \\
\text { (Pre-test II) }\end{array}$ & Post-test II & Gain Post-test II \\
\hline Nilai Maksimum & 80,00 & 100,00 & \\
Nilai Minimum & 50,00 & 70,00 & \\
Rerata (mean) & 59,38 & 82,50 & 0,57 \\
Median & 60,00 & 80,00 & (sedang) \\
Modus & 60,00 & 80,00 & \\
Std.deviasi & 8,78 & 9,84 & \\
\hline
\end{tabular}

Berdasarkan Tabel 3 dapat diketahui bahwa terjadi peningkatan nilai rata-rata kemampuan peserta didik dalam menggali informasi penting dari teks narasi sejarah terjadi cukup signifikan. Nilai Gain yang diperoleh jika dibandingkan dengan hasil belajar pada posttest di siklus I diperoleh nilai Gain 0,57 dengan kriteria Gain sedang. Di akhir siklus II di mana 
diperoleh nilai rata-rata hasil belajar kognitif yang sedikit melebihi nilai kriteria ketuntasan minimal (KKM) yaitu 82,50 mengindikasikan kegiatan tindakan diakhiri cukup di siklus II.

\section{Pembahasan}

Tindakan-tindakan untuk meningkatkan kemampuan peserta didik dalam menggali informasi penting dari teks narasi sejarah dilakukan sebanyak dua siklus. Siklus tindakan dihentikan setelah tujuan penelitian tindakan telah tercapai atau rata-rata hasil belajar kognitif peserta didik telah mencapai atau melebihi nilai kriteria ketuntasan minimal (KKM).

Kendala yang ditemui di awal kegiatan adalah belum terbiasanya peserta didik dengan pembelajaran daring berbantuan video pembelajaran karena menurut pendapat beberapa peserta didik umumnya video hanya digunakan sebagai sarana hiburan. Hal ini disiasati oleh pendidik dengan selain menggunakan video yang memiliki subtitle, jalannya proses pembelajaran pada peserta didik juga dilengkapi dengan Lembar Kerja Peserta Didik (LKPD) sebagai sarana konfirmasi apakah peserta didik memang benar-benar menyimak konten video pembelajaran yang telah disajikan.

Meningkatnya nilai rata-rata kemampuan peserta didik dalam menggali informasi penting dari teks narasi sejarah di akhir siklus II tidak dapat lepas dari usaha pendidik dalam memfokuskan perhatian peserta didik dalam kegiatan menyimak video pembelajaran. Semakin fokus seseorang dalam mengamati sesuatu semakin mudah dalam mengingat apa yang menjadi suatu perhatian (Umainingsih et al., 2017). Selain itu, meningkatnya nilai rata-rata kemampuan peserta didik dalam menggali informasi penting dari teks narasi sejarah juga tidak lepas dari adanya penguatan (reinforcement) yang dilakukan oleh pendidik selama kegiatan belajar mengajar berlangsung. Penguatan dalam bentuk pemberian motivasi dan semangat karena berkaitan dengan sejarah membuat peserta didik bersemangat untuk mengikuti kegiatan belajar mengajar. Hasil penelitian yang telah dilakukan oleh Wiegand \& Geller (2005), Supriyo (2016), Zebua (2017), dan Rumfola (2017) mendukung hasil penelitian tindakan ini di mana pemberian penguatan positif tidak hanya memberikan dampak yang baik terhadap proses belajar mengajar tetapi juga meningkatkan capaian hasil belajar peserta didik dalam suatu kegiatan proses pembelajaran.

Penggunaan multimedia dalam hal ini video pembelajaran tidak hanya dapat menarik minat belajar peserta didik tetapi juga dapat meningkatkan kemampuan menyimak dan selanjutnya dapat meningkatkan kemampuan peserta didik dalam menggali berbagai informasi dari video yang disajikan. Meningkatnya kemampuan menyimak peserta didik setelah dibelajarkan dengan bantuan video pembelajaran juga sejalan dengan hasil penelitian yang 
dilakukan oleh Mardiah, (2013), Krismantio et al., (2014), Tias, (2015), Nurani et al., (2018), dan Sutinah, (2018) di mana penggunaan media audio visual (multimedia) memberikan pengaruh positif terhadap kemampuan menyimak pada peserta didik.

\section{SIMPULAN}

Berdasarkan keseluruhan kegiatan penelitian tindakan kelas sebanyak dua siklus dapat disimpulkan bahwa terdapat peningkatan kemampuan peserta didik dalam menggali Informasi penting pada teks narasi sejarah berbantuan video pembelajaran di kelas VI SDN 1 Dopang. Hal ini dapat di lihat dari nilai Gain pada siklus I $(0,21)$ yang berada pada kategori rendah (belum signifikan) dan nilai Gain pada siklus II $(0,57)$ yang berada pada kategori sedang (cukup signifikan).

\section{DAFTAR PUSTAKA}

Akhyar, F. (2019). Pembelajaran Keterampilan Berbahasa dalam Kurikulum 2013 Sekolah Dasar. Prosiding Seminar Nasional 2019 Bahasa, Sastra, Dan Pembelajarannya Di Era Digital, 77-90.

Cheng, K. K., Thacker, B. A., Cardenas, R. L., \& Crouch, C. (2004). Using an online homework system enhances students' learning of physics concepts in an introductory physics course. American Journal of Physics, 72(11), 1447-1453. https://doi.org/10.1119/1.1768555

Destiningsih, N., Usodo, \& Mardiyana, M. (2013). The Effectiveness of Cooperative Learning Model Numbered Head Together (NHT) and Make a Match on Student Mathematics Learning Achievement in terms of Student Social Skill in Class X Vocation School in Wonogiri Regency Year 2012/2013. Journal of Scientific Mathematics Education, 2(1), 1-12.

Erfan, M., Maulyda, M. A., Gunawan, G., Sari, N., \& Ratu, T. (2020). Enhancing Students Ability in Analyzing Image Formation on Lens and Mirror Using Ray Optics. Journal of Physics: Conference Series, 1471, 012061. https://doi.org/10.1088/1742$\underline{6596 / 1471 / 1 / 012061}$

Hake, R. R. (1998). Interactive-engagement versus traditional methods: A six-thousandstudent survey of mechanics test data for introductory physics courses. American Journal of Physics, 66(1), 64-74. https://doi.org/10.1119/1.18809

Inah, E. N. (2013). Perana Komunikasi dalam Pendidikan. AL-TA'DIB: Jurnal Kajian Ilmu Kependidikan, 6(1), 176-188. https://doi.org/10.31332/atdb.v6i1.299 
Krismantio, A., Utami, S., \& Sukmawati, S. (2014). Peningkatan Kemampuan Menyimak Menggunakan Media Audio pada Peserta Didik Kelas V SD. Jurnal Pendidikan Dan Pembelajaran Khatulistiwa, 3(2), 1-12.

Mardiah, A. (2013). Penggunaan Media Film untuk Meningkatkan Kemampuan Menyimak pada Mata Pelajaran Bahasa Indonesia Siswa Tunarungu Kelas VII SMPLB. JASSI Anakku, 12(1), 19-27.

Nurani, R. Z., Nugraha, F., \& Sidik, G. S. (2018). Penggunaan Media Audio Visual dalam Pembelajaran Menyimak Dongeng di Era Digital. EduHumaniora: Jurnal Pendidikan Dasar, 10(2), 78-84.

Rahayu, I. (2013). Peningkatan Keterampilan Menyimak Cerita Menggunakan Media Audio Visual Kelas V SD. JPGSD, 1(2), 1-9.

Rumfola, L. (2017). Positive Reinforcement P ositively Helps Students in the Classroom. Brockport.

Supriyo. (2016). The Implementation of Practice Generalization Reinforcement (PGR) Learning Strategy to Improve English Grammar Learning Outcomes in Junior High School. IOSR Journal of Research \& Method in Education, 6(6), 50-54. https://doi.org/10.9790/7388-0606045054

Sutinah, S. (2018). Apakah Media Audio Visual dapat Meningkatkan Kemampuan Menyimak? Jurnal Pendidikan: Riset Dan Konseptual, 2(3), 287. https://doi.org/10.28926/riset_konseptual.v2i3.64

Sutipnyo, B., \& Mosik, M. (2018). The Use of Numbered Heads Together (NHT) Learning Model with Science, Environment, Technology, Society (SETS) Approach to Improve Student Learning Motivation of Senior High School. Jurnal Pendidikan Fisika Indonesia, 14(1), 26-31. https://doi.org/10.15294/jpfi.v14i1.13929

Tias, S. W. (2015). Penggunaan Media Video untuk Meningkatkan Kemampuan Menyimak Dongeng pada Siswa Kelas II MI Sirojul Huda Rejoso Pasuruan Tahun Pelajaran 2014/2015. http://repository.unej.ac.id/handle/123456789/65216

Umainingsih, M. B., Alexon, A., \& Kurniah, N. (2017). Memory’s Learning Model Implement to Increase Memory and Studying Achievement Mathematics. DIADIK: Jurnal Ilmiah Teknologi Pendidikan, 7(2), 87-97.

Wiegand, D. M., \& Geller, E. S. (2005). Connecting Positive Psychology and Organizational Behavior Management. Journal of Organizational Behavior Management, 24(1-2), 3-25. https://doi.org/10.1300/J075v24n01_02 
Muryanti, dkk. (2020). Meningkatkan Kemampuan Peserta...

Zebua, K. A. D. P. (2017). The use of verbal reinforcement to motivate the 11th grade students of SMA Budya Wacana Yogyakarta to Speak English. Universitas Sanata Dharma. 